\title{
The 10th National People's Congress in China: A Note on State Personnel Changes and Economic Achievements
}

KJELD ERIK BRøDSGAARD

The two-week long Spring 2003 Meeting of the 10th National People's Congress (NPC) witnessed the completion of the leadership transition that had been initiated at the 16th Party Congress in November 2002. The new state and government leaders were elected without drama or open factional in-fighting. Thus the impression that Chinese politics has entered a phase of predictable institutionalization has been strengthened.

On March 15, 2003 the 2,985 deputies of the 10th National People's Congress cast their votes to elect the new General Secretary of the CCP, Hu Jintao, as President of the PRC (Beijing Xinhua News 2003). He succeeded Jiang Zemin who graciously stepped down after having served for two terms. Member of the Politburo Standing Committee, Zeng Qinghong, who is widely regarded as Jiang Zemin's right-hand man, was appointed Vice-President. The former Mayor and First Party Secretary of Shanghai, Wu Bangguo, was elected to succed Li Peng as Chairman of the NPC and Wen Jiabao, the number three man in the power hierarchy, took over the position of Prime Minister from Zhu Rongji, after Zhu's ten-year tenure. These appointments were all expected.

On March 17, the NPC meeting finalized the line-up of the new State Council, nominated by Premier Wen Jiabao, and elected Huang Ju, Wu Yi, Zeng Peiyuan and Hui Liangyu as Vice Premiers and Zhou Yongkan, Cao Gangchuan, Tang Jiaxuan, Hua Jianmin and Chen Zhili as State Councillors. The meeting also approved the composition of the eight Special Committees of the 10th NPC.

The full State Council, approved by the NPC, consists of the following 35 members (Foreign Broadcast Information Service 2003): 
TABLE 1: Composition of the State Council, Elected at the 10th NPC

\begin{tabular}{|c|c|}
\hline Name & Position \\
\hline Wen Jiabao & Premier \\
\hline Huang Ju & Executive Vice Premier \\
\hline $\mathrm{Wu} \mathrm{Yi}$ & Vice Premier \\
\hline Zeng Peiyan & Vice Premier \\
\hline Hui Liangyu & Vice Premier \\
\hline Zhou Yongkang & State Councillor and Minister of Public Security \\
\hline Cao Gangchuan & State Councillor and Minister of Defence \\
\hline Tang Jiaxuan & State Councillor \\
\hline Hua Jianmin & State Councillor and State Council General Secretary \\
\hline Chen Zhili & State Councillor \\
\hline Li Zhaoxing & Minister of Foreign Affairs \\
\hline Ma Kai & Minister, State Development and Reform Commission \\
\hline Zhou Ji & Minister of Education \\
\hline Xu Guanhua & Minister of Science and Technology \\
\hline Zhang Yunchuan & $\begin{array}{l}\text { Minister, Comm. for Science, Technology and Industry for National } \\
\text { Defence }\end{array}$ \\
\hline Li Dezhu & Minister, State Ethnic Affairs Commission \\
\hline Xu Yongyue & Minister of State Security \\
\hline Li Zhilun & Minister of Supervision \\
\hline Li Xueju & Minister of Civil Affairs \\
\hline Zhang Fusen & Minister of Justice \\
\hline Jin Renqing & Minister of Finance \\
\hline Zhang Boling & Minister of Personnel \\
\hline Zheng Silin & Minister of Labour and Social Security \\
\hline Tian Fengshan & Minister of Land and Resources \\
\hline Wang Guangtao & Minister of Construction \\
\hline Liu Zhijun & Minister of Railways \\
\hline Zhang Chunxian & Minister of Communications \\
\hline Wang Xudong & Minister of Information Industry \\
\hline Wang Shucheng & Minister of Water Resources \\
\hline Lu Fuyuan & Minister of Commerce \\
\hline Sun Jiazheng & Minister of Culture \\
\hline Zhang Wenkang & Minister of Health \\
\hline Zhang Weiqing & Minister, State Comm. for Population and Family Planning \\
\hline Zhou Xiaochuan & Governor of the People's Bank of China \\
\hline Li Jinhua & Auditor-General of the National Audit Office \\
\hline
\end{tabular}

Source: Foreign Broadcast Information Service 2003; Ash 2003. 
Wen Jiabao and all vice premiers are members of the Politburo. Wen Jiabao and Executive Vice Premier Huang Ju are also members of the Standing Committee of the Politburo and are ranked third and sixth respectively (Brødsgaard 2003). Other political heavyweights in the new State Council include State Councillor and Minister of Public Security Zhou Yongkang, a Politburo member and the former Party Secretary of Sichuan province, and State Councillor and Defence Minister Cao Gangchuan, a member of the Politburo and Vice-Chairman of the Central Military Commission.

During the recent SARS crisis there was a minor reshuffle of the State Council due to Zhang Wenkang's ousting as Minister of Public Health on April 20. Zhang, formerly Jiang's personal doctor, was blamed for having concealed the SARS outbreak in Southern China. Instead Vice Premier $\mathrm{Wu}$ Yi took over the co-ordination of the struggle against SARS (Brødsgaard 2003).

The deputies also elected a new State Central Military Commission. It came as no surprise that Jiang Zemin was confirmed in his position as Chairman of the Commission. The membership of this body is always identical with the membership of the CCP Central Military Commission. Since Jiang Zemin kept this position at the 16th Party Congress, he was also expected to continue as Chairman of the State Military Commission. Hu Jintao was re-elected Vice-Chairman together with Minister of Defence Cao Gangchuan and Guo Boxiong, former Executive Chief of Staff of the PLA.

TABLE 2: Composition of the State Central Military Commission Elected at the 10th NPC

\begin{tabular}{|l|l|}
\hline Name & Position \\
\hline Jiang Zemin & Chairman of the CMC \\
\hline Cao Gangchuan & Vice-Chairman of CMC, Member of Politburo, Defence Minister \\
\hline Guo Boxiong & Vice-Chairman of CMC, Member of Politburo \\
\hline Hu Jintao & $\begin{array}{l}\text { Vice-Chairman of CMC, General Secretary of CCP, President of } \\
\text { the PRC }\end{array}$ \\
\hline Li Jinai & Member of CMC, Director of General Armaments Department \\
\hline Liang Guanglie & Member of CMC, Chief of General Staff \\
\hline Xu Caihou & $\begin{array}{l}\text { Member of CMC, Director of the General Political Department } \\
\text { of the PLA }\end{array}$ \\
\hline
\end{tabular}

Source: Foreign Broadcast Information Service 2003; Ash 2003. 
Some analysts have claimed that by Jiang's remaining as Chairman of the Central Military Commission, the transition to the new fourth leadership with $\mathrm{Hu}$ Jintao as its core was not fully completed. Instead a kind of 'Deng Xiaoping scenario' had evolved with the old leader (Jiang) retaining ultimate power via his control over the armed forces. However, Jiang is not Deng Xiaoping and does not enjoy the same status as Deng, who never seemed to need a formal top position in order to wield supreme power. Second, Jiang is himself not a military man and even though he has appointed most of the serving PLA generals, he does not command the same prestige among the military as Deng, who served as a military commander in the Second Field Army during the civil war and later became PLA Chief of Staff. Third, Jiang is not supported by a cohesive group of party elders. In fact, in February 2003 a group of retired party elders wrote a letter to Hu Jintao and Wen Jiabao encouraging them to pursue a path different from that of Jiang Zemin (Zheng 2003). Fourth, there does not seem to exist a Politburo decision, as there was in 1987, giving the retired leader the right to intervene in major decisions. Fifth, it cannot be ruled out that $\mathrm{Hu}$ Jintao perhaps prefers a slow and gradual power transition, whereby the old leader still plays an important role, while the new leader consolidates his power. To assume that there is a political cleavage between a $\mathrm{Hu}$ and a Jiang faction is to analyse political change in China within a paradigm of factionalism (Brødsgaard 2003). Evidence seems to point to an alternative framework for analysis, namely that Chinese politics is increasingly characterized by institutionalization and normativization (ibid.; Nathan 2003). From such a perspective it makes sense for Jiang to stay rather than have him pull strings from behind the curtain.

\section{Institutional Reform}

The 10th NPC continued the institutional reform initiated at the 9th NPC in 1998. At the meeting in 1998, Zhu Rongji and Luo Gan outlined an ambitious plan which involved reducing the 41 ministerial-level working departments (ministries and commissions) of the State Council to 29 and downsizing central-level staff by 50 percent (Luo Gan 1998). Provincial-level agencies were to be cut from 55 to 40 and county-level agencies from 28 to 18. According to Zhu Rongji, a number of ministries such as the Ministry of the Coal Industry, the Ministry of the Metallurgic Industry, the Ministry of Machine-Building Industries, the Ministry of Power, the Ministry of the Chemical Industry, and the Ministry of Internal Trade were to be reorganized as internal bureaux $(j u)$ within the 
State Economic and Trade Commission (SETC). Other ministries such as the Ministry of the Electrical Industry, the Ministry of Post and Communications, and the Ministry of Radio, Film and Television would be merged into a new Ministry of Information. In 1999 a China Securities Regulatory Committee was added so that there were 54 ministeries, commission, offices and directly subordinated organs of the State Council (Brødsgaard 2002).

At the recent 10th NPC, the number of ministerial-level working departments of the State Council was further reduced by one from 29 to 28 (Liu 2003; http://news.xinhuanet.com/2003-08/19). This was effected by merging the former State Economic and Trade Commission with the Ministry of Foreign Trade and Economic Corporation to create a new Ministry of Commerce. The State Economic and Trade Commission was created in 1993 and put under Vice-Premier Zhu Rongji's control. The SETC was to become Zhu Rongii's power base in his successful bid to take over the post of Premier after Li Peng. It seems only logical that an organ so much associated with Zhu Rongji could not survive the retirement of its creator.

The State Development Planning Commission was renamed the State Development and Reform Commission and put in charge of economic restructuring. This also signifies the end of an era. In the past the State Planning Commission was a cornerstone in running a centrally planned economy. With the introduction of the market economy, this relic from the Stalinist past became obsolete.

Moreover at the 10th NPC, the State Family Planning Commission was renamed the State Population and Family Planning Commission. Finally two new institutions with the status of institutions directly under the State Council (zhishu danwei) were established: the State Asset Management Commission, responsible for the reorganization of the state-owned enterprises, and the China Banking Regulatory Commission.

The current restructuring has not resulted in any reduction of the size and numbers of the State Council. Thus there are still 54 central government organs, including the organs directly subordinated to the State Council. But there has been a redefinition of functions, resulting in a reallocation of the bianzhi (central personnel allocations).

In 1998 central government leaders also had stressed the need for reducing the administrative staff at all levels by 50 percent in a threestage process of administrative reform, starting with the central government apparatus and ending with local reform (Luo Gan 1998). This was effected at the centre where, for example, the staff of the State Coun- 
cil was reduced from 32,000 to 16,000 in a process of redefining government functions and reallocating staff. It was the original intention to extend the trimming of administrative personnel to the local level where most of the 10 million strong bureaucracy work. But the plan met with strong resistance and the central government had to reduce cutbacks in staff to 20 percent rather than the planned 50 percent. Zhu Rongji mentions in his work report that the number of the country's administrative personnel was cut by 1.15 million (Zhu Rongji 2003). However, given that there were 9.66 million civil servants in 1998, this would only represent a 11.9 percent reduction. Once again it has proven difficult to effect substantial cutbacks. The bureaucrats will fight to keep their positions and the further one goes down the administrative hierarchy, the more difficult it is for the central leadership to effect the desired changes.

\section{Economic Gains}

In his lengthy review of Government Work, 1998-2002, the outgoing Premier Zhu Rongji outlined a picture of economic and social progress (Zhu Rongji 2003). He cited a number of quantitative indicators to support his claim of continued economic progress. For the five-year period in question, GDP, measured in constant prices, had risen 7.7 percent on annual basis. Foreign trade had increased from US\$ 352 billion to US\$ 621 billion, thereby raising China's global rating as a trading nation from 10 th to 5 th place.

Exports had risen from US\$ 183 billion to US\$ 326 billion. Owing to a continued favourable trade balance, foreign exchange had increased from US $\$ 140$ billion to 286 billion. Cumulative utilized Foreign Direct Investment (FDI) amounted to US\$226 billion for the five-year period. In 2002 alone, China attracted nearly US\$ 54 billion in FDI, overtaking the US as the most attractive destination for FDI.

Zhu mentioned that a number of key infrastructural projects had been completed. They included major water conservancy projects, road building, railway construction and building/expanding 50 airports. Telecommunication was dramatically expanded and the number of fixed-line and mobile telephone subscribers rose from 84 million in 1998 to 421 million by the end of 2002 .

Zhu also reported increases for both urban and rural incomes, although he had to admit that the rise of per capita urban disposable income was more than double the increase of per capita rural income, causing a widening of the urban-rural income gap. He also mentioned that the nine-year compulsory education had become virtually univer- 
TABLE 3: GDP, Trade and FDI Growth, 1998-2002 (in billion US\$)

\begin{tabular}{|l|c|c|c|}
\hline & $\mathbf{1 9 9 8}$ & $\mathbf{2 0 0 2}$ & \% Increase \\
\hline GDP & 981 & 1,282 & 31 \\
\hline Trade & 352 & 621 & 76 \\
\hline Export & 183 & 326 & 78 \\
\hline FDI & 45 & 54 & 20 \\
\hline Foreign Exchange Reserves & 140 & 286 & 104 \\
\hline
\end{tabular}

Source: Zhu Rongii 2003; Zhonghua renmin gongheguo guojia tongji ju 2002.

sal and that average life expectancy had reached 71.8 years-only 4 years lower than that of Denmark.

It should be noted that China's continued economic progress, as reported by Zhu Rongji, had taken place during a period characterized by the onset of the Asian Financial Crisis and stagnating world economic growth-what Zhu in his speech called 'the grim international environment'. In the latter half of 1998, China's exports actually registered a negative growth rate as a result of the Asian Financial Crisis. Still China did not devaluate its currency as many other Asian countries had done.

Although the gains were significant, Zhu Rongji admitted that there were still a number of economic and social difficulties and problems. They included:

- insufficient domestic demand;

- failure of the supply structure to respond to changes in market demand;

- slow rise in the income of farmers and some urban residents;

- rise in unemployment and serious difficulties in some people's livelihood;

- incomplete SOE reform;

- poor state of the market order;

- unacceptably high incidence of serious industrial accidents;

- poor public security in some places;

- degradation of the ecological environment;

- persistence of formalism, bureaucracy, falsification, extravagance and waste among some officials.

In spite of these difficulties, China had performed exceptionally well by most quantifiable international standards.

This is also the picture emerging from the 'Statistical Communiqué on National Economic and Social Development 2002' which was pub- 
lished a few days before the opening of the 10th NPC meeting. The Communiqué showed a rise in GDP in 2002 of 8 percent, compared to 7.3 percent in 2001, to reach a total of 10.298 trillion yuan (US\$ 1.282 trillion). All sectors of the economy showed progress although industrial growth (9.9 percent) again outstripped that of both agriculture (2.9 percent) and services (7.3). Especially output of export-oriented and high-tech products increased rapidly. Thus in 2002 China produced 15 million PCs, 52 million colour TV sets, 31 million air conditioners and 120 million units of mobile telephones, to mention a few of the major industrial commodities.

\section{Summing up}

Economic indicators point to a buoyant economic performance in the 19982002 period. Available statistics also indicate that China was affected by the Asian Financial Crisis, but did not suffer as badly as other Asian countries such as Thailand, Korea, and Indonesia. By 2000 the Chinese economy was back on track with high growth rates and growing interaction with the outside world in terms of foreign trade and FDI inflows.

In the political sphere, the country has recently completed what one observer has termed 'the most orderly, peaceful, deliberate, and rulebound succession in the history of modern China outside of the recent institutionalization of electoral democracy in Taiwan' (Nathan 2003a).

The SARS crisis in China in April-June put the new leadership to the test. $\mathrm{Hu}$ Jintao and Wen Jiabao showed they were capable of acting swiftly and decisively when they fired the Mayor of Beijing and the Minister of Health for their part in attempting to conceal the outbreak of the disease. Paradoxically the SARS crisis seems to have strengthened the legitimacy of the new leadership in the eyes of the Chinese population.

Certainly one does not get the impression that China is entangled in a crisis of government as claimed by some observers (Pei 2002). On the contrary, the party-state seems to have been able to revitalize its organizational machine with new and better trained and educated leaders at all levels of the political-administrative apparatus. Currently the party under the slogan of 'Three Representations' is engaged in a massive project of coopting the booming private sector. Clearly the Chinese party-state constitutes an amazingly resilient authoritarian system (Nathan 2003b) which does not yet seem to have outplayed its historical role.

Kjeld Erik Brødsgaard is Director of the Asia Research Centre and Professor of International Business in Asia/China at the Copenhagen Business School. 
Kjeld Erik Brødsgaard

\section{REFERENCES}

Ash, Robert F. (ed.) 2003. 'Quarterly Chronicle and Documentation.' The China Quarterly 174: 556-606.

Beijing Xinhua News 2003 (March 15).

Brødsgaard, Kjeld Erik 2002. 'Institutional Reform and the Bianzhi System in China.' The China Quarterly 170 (June): 361-86.

— 2003. 'The 16th Party Congress in China: A Note on Personnel Changes.' The Copenhagen Journal of Asian Studies 16: 138-49.

Foreign Broadcast Information Service 2003. FBIS-CHI-2003-0317 (March 17).

Liu, Jen-Kai 2003. 'The Main National Leadership of the PRC.' China aktuell (March): 341-60.

Luo Gan 1998. 'Guanyu guowuyuan jigou gaige fang'an de shuoming' [Explanation of the Draft for Institutional Reform of the State Council]. In Guowuyuan bangongting mishuju and zhongyang jigou bianzhi weiyuanhui bangongshi zongheju (eds), Zhongyang zhengfu zuzhi jigou [Central Government Institutions and Organs]. Beijing: Gaige chubanshe, 1998: 8-17.

Nathan, Andrew 2003a. 'China's Ambiguous Leadership Transition.' Paper presented at the seminar on 'The New Chinese Leadership', Instituto do Oriente, Lisbon (July 8).

— 2003b. 'China's Changing of the Guard: Authoritarian Resilience.' Journal of Democracy 14 (1): 6-17.

National Bureau of Statistics. 'Statistical Communiqué on National Economic and Social Development 2002'. www.stats.gov.cn.

Pei, Minxian 2002. 'China's Governance Crisis.' China Review (Autumn-Winter): 7-10.

'Übersichten' [Overview] 2003. China aktuell (April) 423-39.

Zhonghua renmin gongheguo guojia tongii ju [National Bureau of Statistics of China] 2002. Zhongguo tongii nianjian 2002. Beijing: Zhongguo tongii chubanshe, 2002.

Zheng, Yongnian 2003. 'Interest Representation and the Transformation of the Chinese Communist Party.' The Copenhagen Journal of Asian Studies 16: 57-85.

Zhu Rongji 2003. 'Government Work Report, delivered at the First Session of the National People's Congress on March 5, 2003.' http:/ / china.org.cn. 